\title{
Urinary Tract Cancer TNM Finding v8
}

National Cancer Institute

\section{Source}

National Cancer Institute. Urinary Tract Cancer TNM Finding v8. NCI Thesaurus. Code C140273.

A finding about one or more characteristics of urinary tract cancer, following the rules of the TNM AJCC v8 classification system. 